UDC 94(477)

DOI: 10.24919/2519-058x.7.132975

Sergey KORNOVENKO, orcid 0000-0002-6268-2321

Ph D hab. (History), Professor, Prorector for Research Innovative and International Activities of Bohdan Khmelnytsky National University at Cherkasy (Ukraine, Cherkasy)

s-kornovenko@ukr.net

\title{
A PEASANT COMPONENT IN THE TRANSITION TO THE NEW ECONOMIC POLICY (1921)
}

The contribution deals with the study of the New Economic Policy. The analysis of the declassified documentary data enables the author to expose a high level of socio-political activity of Ukrainian peasants in the early 20-ies of the XXth century. The paper explicates that the Ukrainian peasantry were dissatisfied with the policy of «war communism». Active anti-Soviet stand of peasantry forced the Bolsheviks to reconsider the doctrinal principles of Marxism, particularly its socio-economic component. The peasantry became a real threat to the Bolsheviks'rule, which caused the transition to the New Economic Policy.

Key words: the New Economic Policy, Ukrainian peasantry, socio-political activity of peasants, Ukraine.

Сергій КОРНОВЕНКО, доктор історичних наук, професор, проректор з наукової, інновачійної та міжнародної діяльності Черкаського національного університету імені Богдана Хмельницького (Україна, Черкаси) s-kornovenko@ukr.net

\section{СЕЛЯНСЬКИЙ ФАКТОР ПЕРЕХОДУ ДО НОВОЇ ЕКОНОМІЧНОЇ ПОЛІТИКИ (1921р.)}

Статтю присвячено вивченню нової економічної політики. Автором на основі аналізу розсекречених матеріалів розкрито високий ступінь суспільно-політичної активності украӥнського селянства на початку 20-х років ХХ століття. Висвітлено, щчо селянство України не було задоволено політикою «воєнного комунізму». Активна антирадянська позичія селянства зумовила перегляд більшовиками доктринальних засад марксизму, зокрема сочіально-економічного складника. Перехід до нової економічної політики відбувся завдяки тому, що селянство створило реальну загрозу більшовикам із утримання ними влади.

Ключові слова: нова економічна політика, украӥнське селянство, суспільно-політична активність селянства, Україна.

The statement of the problem. The New Economic Policy (hereafter - NEP) as a socio-cultural phenomenon of the post-revolutionary era has been in the focus of attention of several generations of researches in the context of studying the history of Ukraine of the 1920-ies. This is due to the fact that the NEP is a unique page of socio-political, socio-economic, spiritual, and cultural national history. Firstly, it was one of the first nationwide attempts to move away from rigid administration of economy and social life at the period of the War Communism. Secondly, the NEP period is the renaissance of the Ukrainian national culture started by the Ukrainian revolution. Thirdly, the NEP was the time of the alternative search. 
The analysis of researches. For a long time the Soviet historiography interpreted the transition to NEP as an «accomplishment of Lenin's genius» and the «genius» of the Bolshevik Party (Trapeznikov, 1976: 453-455). Subsequently, this approach was criticized by new Ukrainian and Russian historians (Kulchytskyi, 1996; Morozov, 1993; Kalinichenko, 1997; Danilov, 2006: 26-32; Orlov, 2006: 33-54). However, we believe that modern domestic historiography did not pay much attention to the peasant component as a key one in the transition to NEP. The author of the article aims to investigate the impact of peasant components, including socio-political activity of the peasantry, on the Bolsheviks' decision to introduce the NEP.

In historiographical tradition and socio-political practice of the late XIX - early XX century there was established the unfounded, in our view, understanding of the peasantry as inert, pro-monarchy-minded and conservatively-thinking social groups that can not be self-sufficient and active subject of the historical process in the broad sense of the word. Obviously, such an understanding of the peasantry as being defective and inconsistent in socio-political and socio-economic life was caused by the government's protectionist policies against the peasantry in the late XIX - early XX century (Sviashchenko, 2012).

Later, the idea of the peasantry inferiority was adopted by the Bolsheviks (Lenin, 1968: 362-366; Lenin, 1976: 235, 313, 325-326). They developed the concept of the peasantry as an ally of the proletariat in the struggle for a brighter future. However, the proletariat who supposedly had nothing to lose but their own bonds was declared the leader (Safonov, 2012: 15-18). Instead the farmer was considered an entity with «dual psychology».

In any case in the late XIX - early XX century the peasants stayed obscure. This «Janus in bast shoes» for the majority of the then socium was the object and subject of cognition, as a «thing in itself», which they tried to comprehend while attributing it mostly unusual characteristics, trying to adapt it to the then-known models and schemes. Self-cognition of peasantry as it was and through inherent characteristics did not happen.

However, socio-political activity of the peasantry within the Ukrainian revolution of 1917 - 1921 dramatically disagreed with the impressions of the peasantry and understanding it which dominated in the intellectual space of that period. A thorough analysis of historical events of the early twentieth century clearly shows the politicization and radicalization of peasant consciousness; the phenomenon was reflected in the «Great peasant revolution» that started in 1902. We agree with the V. Danilov's project concerning the peasant revolution of 1902 - 1922. However, as for us, the upper chronological limit requires further discussion, at least in terms of the Ukrainian realities. There are no substantial objections to the idea that the peasant movement of the early twentieth century laid deep foundation to all revolutionary transformations that were experienced by Ukraine and Russia in the first decades of the twentieth century. It is against the background of the peasant revolution the other revolutions were unfolding - national-democratic, social, political ones, and so on. The Peasant Revolution in Ukraine and Russia was a protective reaction of the peasantry of Ukraine and Russia to the objective, inherent to all developed countries process of primitive accumulation of capital at the expense of the impoverishment of the peasantry, and as a result - its liquidation under the influence of industrial civilization. The main slogan and goal of the peasant revolution were: «the land and the right to freely farm on it» (Danilov, 1992: 310-321; Danilov, 1996: 4-23; Kondrashin, 2008: 70-74).

In places where the above mentioned peasant ideal contrasted with the position of a political regime peasant resistance movement flared up. For instance, within the first two decades 
of July, 1919 in Ukraine there were 207 armed peasant uprisings against the Soviet rule. Of these, 111 occurred in the Kyiv region, 37 - in the Poltava region, 20 - in the Volyn region, 14 - in the Kherson region, and 12 - in Chernihiv and Podillya (Zinchenko, 2008: 137).

The anti-Soviet peasant armed resistance movement did not stop in 1920 - early 1921. The peasants of Ukraine did not accept the policy of the «war communism». During this period the wave of the anti-Soviet armed peasant uprisings swept across Ukraine. The documents which have been inaccessible for the researchers for a long period, objectively illustrate the then situation in the country which ensued with the end of large-scale hostilities.

For instance, making a brief review of the situation in Ukraine in June, 1920, a special department in the Southwestern Front reported: «Ukraine is experiencing another wave of uprisings. In the Kharkiv, Donetsk, and Chernihiv provinces the uprising are of a rolling nature, they spread there from the neighboring Kursk, Ekaterinoslav, and Kiev provinces, where the uprising have an organized. The Kiev and Ekaterinoslav provinces are the cradles of the uprisings. These outbreaks are caused by the erroneous actions of the members of the grain requisitioning squads» (Kratkij obzor, 1998: 259).

In its info summary of June 16-30, 1920, the secret department of the Cheka informed: «The Kharkiv province. In the Ahtyrsk district due to the decisive means for pumping bread the mood of the peasantry changed for the worse. The party is working imperfectly, and the peasants have little or no understanding of the problems of the Soviet power» (Iz informacionnoj svodki sekretnogo otdela, 1998: 268).

V. Antonov-Ovseyenko reported: "As of the beginning of June the mood of the peasants of the Katerynoslav region are not in favor of the Soviet power. As of June from 226 districts (of 278 districts in the province), there were: engulfed in uprisings -6 affected by ... gang violence -64 , hostile, but not active -91 , the kulak-loyal -63 , and pro-Soviet -3 . Joining the gangs by the poor people should be considered first, as a reflection of the natural process of the stratification of the country folk, and secondly, as an error which lies in it that we have not timely considered the moment and did not assemble the poor through an appropriate form of organization. As for the middle peasants, they can be an excellent material for use under the following conditions: 1) if we make them interested in robbing the kulaks; 2) will implement our policy of transferring the main burden on the kulaks» (Iz doklada, 1998: 277-278).

The Katerynoslav Cheka, reporting on its activities of July, 15 through August, 1, 1920, informed: «In connection with the use of the repressive means within implementing the grain requisition, the strengthening of the hostility to the Soviet power is being observed among the peasants. There are cases of disbanding the Soviets and replacing them by the village elders. As a result of a series of repressive operations the implementation of the requisition has advanced but the banditry still has considerable dimensions, including its impact on those strata of the peasantry who used to be passive» (Iz dvuhnedel'noj svodki Ekaterinoslavskoj gubcheka, 1998: 279).

The info summary of August, 15-20, 1920 reads: «The Kiev province. The mood of the population is good and cheerful. In the counties that were not occupied by the Polish-Petlyura troops, the mood of the peasants is pro-Petlyura and the kulaks are tuning the peasants against the Soviet power. The Poltava province. The attitude of the peasants to the Communist Party is hostile. The Kherson province. The mood of the population of the Olexandriya county is pro-Petlyura. The populace is hiding weapons, even guns. The rebellion is highly possible» (Iz informacionnoj svodki, 1998: 295).

From a two week info summary of the of the Cheka Secret department construction (September, 15-30, 1920): «The Katerynoslav province. The province is an unfavorable ground 
for the Soviet construction. The mood of all the layers of the population is unsatisfactory. The peasants are hostile. The Podillya province. In the Vinnitsa district the Pikivtsi and Lyupynets townships the locals have completely rejected the grain requisition. The situation has turned so alarming that the requisitioners refused to work without the support group. The Donetsk province. The peasantry have absolutely no idea of the Soviet power and the Communist Party» (Iz dvuhnedel'noj informacionnoj svodki, 1998: 323).

The Cheka secret department, analyzing the situation in the areas of Ukraine subject to the Bolsheviks, testified: «Kherson, the Mykolayiv province. Soviet institutions are poisoned by anti-Semitism. The food distributing committees render completely inactive, even the working population and the workers of the provincial towns get nothing from what has been guaranteed by the rationing system. The free market price on bread is 300 rubles. The township and village Soviet institutions are manned with the outright counter-revolutionaries with no possibility of replacing them due to the deficit of specialists. The lack of discipline is characteristic of the Soviet institutions» (Iz dvuhnedel'noj informacionnoj svodki, 1998: 326).

The report of a secret department of the Cheka on the insurgency as of November, 1920, contains the following: «The last experience of vranghelivschyna (the general Vranghel's influence) proved that the Ukrainian kulaks and the peasantry in general seem to have remained loyal, but it does not mean that the well-to-do elements of the village have fully and readily joined the Soviet power. Rich peasants are afraid of the landlords' sticks, the whips of the policemen and of the heavy tribute to the governor, but they are also afraid of the proletarian consistency in building communism. The Ukrainian kulaks want to become «masters» in the countryside, individual and sole, and not to depend on the town and the workers. In short three years of revolution so many big and minor governments besieged the Ukrainian countryside that «anarchy» seems to a Ukrainian «farmer» to be kind of some «ideal» healing of all the evil possible» (Doklad, 1998: 365).

Gradually, by the spring of 1921, a negative attitude of the peasantry to the grain quisition had fully manifested itself. It couldn't stay unnoticeable. A. Tsyurupa reported: «Demoralisation, disorganization, and the destruction of our staff are everywhere. It is only on the front of the Ukrainian grain requisition that 1700 grain collectors were killed» (Desyatyj s"ezd, 1963: 422). Let us pay tribute to the Bolshevik leader and his ability to objectively assess the reality. V. Lenin said: «The peasantry are dissatisfied with that form of relationships that we have established, they do not want this form of relationship, and are unwilling to exist like this any more. Definitely. They have expressed it explicitly. This is the will of the public masses of the working population» (Lenin, 1974: 59).

March 1921 became the climax of the crisis. The country was shocked by the news of the uprising in the town of Kronstadt. It was raised by the sailors, most of whom were the peasants dissatisfied with the policy of «war communism». The Bolsheviks were facing the real threat of losing power. «The economics of spring 1921 turned to the policy of «Kronstadt» (Lenin, 1974: 387). Under the pressure from the anti-Bolshevik position of the peasantry and other socio-economic and socio-political factors, on February 4, 1921, in his speech at the Moscow conference of the metalworkers V. Lenin put forward a general problem to be solved: reconsidering the relationships of workers and peasants. In this regard, he wrote about the necessity to satisfy the desire of the peasantry and replace grain requisition (as extracting surplus) by grain taxation (Lenin, 1973: 306-309).

The conclusions. Thus, in the early 20 -ies of the XXth century dissatisfaction Ukrainian peasants by the Soviet authorities, as evidenced by the mass character and the scale of 
peasant uprisings in Ukraine during this period, in fact, forced the state and the party Soviet leaders to review the economic theory and practice of Marxism. Without the introduction of the NEP, the Bolsheviks would not have retained power in their hands. In this regard, being pressured by the peasants they opened the doors of commodity-money relations as economic incentives of the production, especially in agriculture. Refusal from the policy of «war communism» meant the revival of the market management mode, mainly for the peasants.

\section{BIBLIOGRAPHY}

Данилов, 1992 - Данилов В. Аграрные реформы и аграрная революция в России // Великий незнакомец: крестьяне и фермеры в современном мире. Москва, 1992. С. 310-321.

Данилов, 1996 - Данилов В. Крестьянская революция в России, 1902 - 1922 гг. // Крестьяне и власть. Москва-Тамбов, 1996. С. 4-23. [Электронный ресурс] Режим доступа: http: www.patriotica.ru/history/danilov_rev.html

Данилов, 2006 - Данилов В. К вопросу о понимании нэпа // НЭП: экономические политические и социокультурные аспекты. Москва: РОССПЭН, 2006. С. 26-32.

Десятый съезд, 1963 - Десятый съезд РКП(б). Март 1921 год. Стенографический отчет. Москва, 1963.915 с.

Доклад, 1998 - Доклад секретного отдела ВЧК о повстанческом движении по состоянию на ноябрь 1920 г. // Советская деревня ВЧК - ЩГПУ - НКВД. Документы и материалы. В 4-х т. / т. 11918 - 1922 гг. / Под ред. А. Береловича, В. Данилова. Москва: РОССПЭН, 1998. С. 363-379.

Зінченко, 2008 - Зінченко А. Нариси історії Подільського селянства: 1917 - 1930 рр. Вінниця, $2008.344 \mathrm{c}$.

Из двухнедельной информационной сводки, 1998 - Из двухнедельной информационной сводки секретного отдела ВЧК за 15-30 сентября 1920 г. // Советская деревня ВЧК - ЩГПУ НКВД. Документы и материалы. В 4-х т. / т. 11918 - 1922 гг. / Под ред. А. Береловича, В. Данилова. Москва: РОССПЭН, 1998. С. 322-328.

Из двухнедельной сводки Екатеринославской губчека, 1998 - Из двухнедельной сводки Екатеринославской губчека за время с 15 июля по 1 августа 1920 г. // Советская деревня ВЧК ЩГПУ - НКВД. Документы и материалы. В 4-х т. / т. 11918 - 1922 гг. / Под ред. А. Береловича, В. Данилова. Москва: РОССПЭН, 1998. С. 279-281.

Из доклада, 1998 - Из доклада народного комиссара внутренних дел Украины Антонова в ВЧК о политическом положении Екатеринославской губернии по его личным наблюдениям // Советская деревня ВЧК - ЩГПУ - НКВД. Документы и материалы. В 4-х т. / т. 11918 - 1922 гг. / Под ред. А. Береловича, В. Данилова. Москва: РОССПЭН, 1998. С. 277-278.

Из информационной сводки, 1998 - Из информационной сводки за 1-15 августа 1920 г. // Советская деревня ВЧК - ЩГПУ - НКВД. Документы и материалы. В 4-х т. / т. 11918 - 1922 гг. / Под ред. А. Береловича, В. Данилова. Москва: РОССПЭН, 1998. С. 295-299.

Из информационной сводки секретного отдела, 1998 - Из информационной сводки секретного отдела ВЧК за 16 - 30 июня 1920 г. // Советская деревня ВЧК - ЩГПУ - НКВД. Документы и материалы. В 4-х т. / т. 11918 - 1922 гг. / Под ред. А. Береловича, В. Данилова. Москва: РОССПЭН, 1998. С. 267-276.

Калініченко, 1997 - Калініченко В. Селянське господарство в Україні в період НЕПу: Історико-економічне дослідження. Харків: Основа, 1997. 400 с.

Кондрашин, 2008 - Кондрашин В. «Крестьянская революция в России. 1902 - 1922 гг.»: научный проект и научная концепция (предварительные заметки) // Український селянин. 2008. Випуск 11. С. 70-74.

Краткий обзор, 1998 - Краткий обзор положения на Украине (по сведениям особого отдела Юго-Западного фронта на 15-30 апреля) // Советская деревня ВЧК - ЩГПУ - НКВД. Документы и материалы. В 4-х т. / т. 11918 - 1922 гг. / Под ред. А. Береловича, В. Данилова. Москва: РОССПЭН, 1998. С. 259-261.

Кульчицький, 1996 - Кульчицький С. Комунізм в Україні: перше десятиріччя (1919 1928 рр.). Київ: Основи, 1996. 396 с.

Ленін, 1973 - Ленін В. І. Повне зібрання творів: У 55 т. Київ: Видавництво політичної літератури, 1973. Т. $42.608 \mathrm{c.}$

Ленін, 1974 - Ленін В. І. Повне зібрання творів: У 55 т. Київ: Видавництво політичної літератури, 1974. Т. $43.527 \mathrm{c.}$ 
Ленин, 1968 - Ленин В. Объединительный съезд РСДРП. 10-25 апреля 1906 г. // Полное собрание сочинений. Москва, 1968. Т. 12. С. 362-366.

Ленин, 1976 - Ленин В. Аграрная программа социал-демократии в первой русской революции 1905 - 1907 годов // Полное собрание сочинений. Москва, 1976. Т. 16. С. 235, 313, 325-326.

Морозов, 1993 - Морозов А. Село і гроші. Українська кредитна кооперація в добу НЕПу. Черкаси, 1993. 274 с.

Орлов, 2006 - Орлов И. НЭП в региональном ракурсе: от усредненных оценок к многообразию // НЭП: экономические политические и социокультурные аспекты. Москва: РОССПЭН, 2006. C. 33-54.

Сафонов, 2012 - Сафонов Д. Крестьянство как объект и субъект процесса модернизации // Вісник Черкаського університету. Серія історичні наук № 35 (248). Черкаси, 2012. С. 15-18.

Священко, 2012 - Священко 3. Проурядові аграрні ініціативи в Російській імперії на початку ХХ ст. Умань: ФОП Жовтий О. О., 2012. 343 с.

Трапезников, 1976 - Трапезников С. П. Ленинизм и аграрно-крестьянский вопрос: В 2 т. Т. 1. Москва: Мысль, 1976. 567 с.

\section{REFERENCES}

Danilov, 1992 - Danilov V. Agrarnye reformy i agrarnaya revolyuciya v Rossii [The agrarian reforms and the agrarian revolution in Russia] // Velikij neznakomec: krest'yane i fermery v sovremennom mire [A great stranger: peasants and farmers in the modern world]. Moskva, 1992. Pp. 310-321. [in Russian].

Danilov, 1996 - Danilov V. Krest'yanskaya revolyuciya v Rossii, 1902 - 1922 gg. [The peasant revolution in Russia, 1902 - 1922] // Krest'yane i vlast' [Peasants and power]. Moskva-Tambov, 1996. Pp. 4-23. Retrieved from http: www.patriotica.ru/history/danilov_rev.html [in Russian]

Danilov, 2006 - Danilov V. K voprosu o ponimanii nehpa [On the issue of understanding the NEP] // NEHP: ehkonomicheskie, politicheskie i sociokul'turnye aspekty [NEP: Economic, political and sociocultural aspects]. Moskva: ROSSPEHN, 2006. Pp. 26-32. [in Russian]

Desyatyj s"ezd, 1963 - Desyatyj s"ezd RKP(b). Mart 1921 god. Stenograficheskij otchet [The tenth congress of the Russian Communist Party (of the Bolsheviks). March, 1921. The Verbatim report]. Moskva, 1963. 915 p. [in Russian]

Doklad, 1998 - Doklad sekretnogo otdela VCHK o povstancheskom dvizhenii po sostoyaniyu na noyabr' $1920 \mathrm{~g}$. [The report of the Cheka secret department on the insurgencies as of November, 1920] // Sovetskaya derevnya VCHK - SHCHGPU - NKVD. Dokumenty i materialy [The Soviet village Cheka - SCHHPU - NKVD. Documents and materials]. V 4-h t. T. 1: 1918 - 1922 gg. / Pod red. A. Berelovicha, V. Danilova. Moskva: ROSSPEHN, 1998. Pp. 363-379. [in Russian]

Zinchenko, 2008 - Zinchenko A. Narysy istorii Podilskoho selianstva: 1917 - 1930 rr. [The essays on the history of the Podolsk province peasants: 1917 - 1930]. Vinnytsia, 2008. 344 p. [in Ukrainian]

Iz dvuhnedel'noj informacionnoj svodki, 1998 - Iz dvuhnedel'noj informacionnoj svodki sekretnogo otdela VCHK za 15-30 sentyabrya 1920 g. [From the two-week info summary of the secret department of the Cheka as of September 15-30,1920] // Sovetskaya derevnya VCHK - SHCHGPU - NKVD. Dokumenty i materialy [The Soviet village Cheka-SCHHPU - NKVD. Documents and materials.]. V 4-h t. T. 1: 19181922 gg. / Pod red. A. Berelovicha, V. Danilova. Moskva: ROSSPEHN, 1998. Pp. 322-328. [in Russian]

Iz dvuhnedel'noj svodki Ekaterinoslavskoj gubcheka, 1998 - Iz dvuhnedel'noj svodki Ekaterinoslavskoj gubcheka za vremya s 15 iyulya po 1 avgusta 1920 g. [From the two-week info summary of the Ekaterynoslavprovince Cheka as of July, 15 through August, 1, 1920] // Sovetskaya derevnya VCHK - SHCHGPU - NKVD. Dokumenty i materialy [The Soviet village Cheka SCHHPU - NKVD. Documents and materials]. V 4-h t. T. 1: 1918 - 1922 gg. / Pod red. A. Berelovicha, V. Danilova. Moskva: ROSSPEHN, 1998. Pp. 279-281. [in Russian]

Iz doklada, 1998 - Iz doklada narodnogo komissara vnutrennih del Ukrainy Antonova v VCHK o politicheskom polozhenii Ekaterinoslavskoj gubernii po ego lichnym nablyudeniyam [From the reports of the national Commissioner of Internal Affairs of Ukraine Antonov in the Cheka on the political situation in the Ekaterynoslav province by his personal observations] // Sovetskaya derevnya VCHK SHCHGPU - NKVD. Dokumenty i materialy [The Soviet village Cheka - SCHHPU - NKVD. Documents and materials]. V 4-h t. T. 1: 1918 - 1922 gg. / Pod red. A. Berelovicha, V. Danilova. Moskva: ROSSPEHN, 1998. Pp. 277-278. [in Russian]

Iz informacionnoj svodki, 1998 - Iz informacionnoj svodki za 1-15 avgusta $1920 \mathrm{~g}$. [From the info summary as of August, 1-15,1920] // Sovetskaya derevnya VCHK - SHCHGPU - NKVD. Dokumenty i materialy [The Soviet village Cheka-SCHHPU - NKVD. Documents and materials]. V 4-h t. T. 1: 19181922 gg. / Pod red. A. Berelovicha, V. Danilova. Moskva: ROSSPEHN, 1998. Pp. 295-299. [in Russian] 
Iz informacionnoj svodki sekretnogo otdela, 1998 - Iz informacionnoj svodki sekretnogo otdela VCHK za 16-30 iyunya $1920 \mathrm{~g}$. [From the info summary of the secret department of the Cheka as of June, 16-30, 1920] // Sovetskaya derevnya VCHK - SHCHGPU - NKVD. Dokumenty i materialy [The Soviet village Cheka - SCHHPU - NKVD. Documents and materials]. V 4-h t. T. 1: 1918 1922 gg. / Pod red. A. Berelovicha, V. Danilova. Moskva: ROSSPEHN, 1998. Pp. 267-276. [in Russian]

Kalinichenko, 1997 - Kalinichenko V. Selianske hospodarstvo v Ukraini v period NEPu: Istorykoekonomichne doslidzhennia [Farming in Ukraine during the NEP: Historical and economic research]. Kharkiv: Osnova, 1997. 400 p. [in Ukrainian]

Kondrashin, 2008 - Kondrashin V. «Krest'yanskaya revolyuciya v Rossii. 1902 - 1922 gg.»: nauchnyj proekt i nauchnaya koncepciya (predvaritel'nye zametki) [«The peasant revolution in Russia. $1902-1922 »$ the scientific project and the scientific concept (preliminary notes)] // Ukrainskyi selianyn [Ukrainian peasant]. Kyiv, 2008. Vypusk 11. Pp. 70-74. [in Russian]

Kratkij obzor, 1998 - Kratkij obzor polozheniya na Ukraine (po svedeniyam osobogo otdela YUgoZapadnogo fronta na 15-30 aprelya) [A Brief overview of the situation in Ukraine (on the information of the special department of the South-West Front as of April, 15-30)] // Sovetskaya derevnya VCHK SHCHGPU - NKVD. Dokumenty i materialy [The Soviet village Cheka - SCHHPU - NKVD. Documents and materials]. V 4-h t. T. 1: 1918 - 1922 gg. / Pod red. A. Berelovicha, V. Danilova. Moskva: ROSSPEHN, 1998. Pp. 259-261. [in Russian].

Kulchytskyi, 1996 - Kulchytskyi S. Komunizm v Ukraini: pershe desiatyrichchia (1919 - 1928 rr.) [Communism in Ukraine: the first decade (1919 - 1928)]. Kyiv: Osnovy, 1996. 396 p. [in Ukrainian]

Lenin, 1973 - Lenin V. I. Povne zibrannia tvoriv: U 55 t. [The full collection of manuscripts: In 55 v]. Kyiv: Vydavnytstvo politychnoi literatury, 1973. T. 42. 608 p. [in Ukrainian]

Lenin, 1974 - Lenin V. I. Povne zibrannia tvoriv: U 55 t. [The full collection of manuscripts: In 55 v.]. Kyiv: Vydavnytstvo politychnoi literatury, 1974. T. 43. 527 p. [in Ukrainian]

Lenin, 1968 - Lenin V. Ob'edinitel'nyj s'ezd RSDRP. 10-25 aprelya 1906 g. [The unifying congress of the Russian Social Democratic Labour Party. April, 10-25, 1906] // Polnoe sobranie sochinenij [The Full collection of manuscripts]. Moskva, 1968. T. 12. Pp. 362-366. [in Russian]

Lenin, 1976 - Lenin V. Agrarnaya programma social-demokratii v pervoj russkoj revolyucii 1905 - 1907 godov [The agrarian program of the social democracy in the first Russian revolution of 1905 - 1907] // Polnoe sobranie sochinenij [The Full collection of manuscripts]. Moskva, 1976. T. 16. Pp. 235, 313, 325-326. [in Russian]

Morozov, 1993 - Morozov A. Selo i hroshi. Ukrainska kredytna kooperatsiia v dobu NEPu [Village and money. Ukrainian credit co-operatives in the days of the NEP]. Cherkasy, 1993. 274 s. [in Ukrainian]

Orlov, 2006 - Orlov I. NEHP v regional'nom rakurse: ot usrednennyh ocenok k mnogoobraziyu [NEP in the regional perspective: from the average assessment to the variety] // NEHP: ehkonomicheskie, politicheskie i sociokul'turnye aspekty [NEP: Economic, Political, and Socio-cultural aspects]. Moskva: ROSSPEHN, 2006. Pp. 33-54. [in Russian]

Safonov, 2012 - Safonov D. Krest'yanstvo kak ob'ekt i sub'ekt processa modernizacii [Peasantry as an object and subject of the modernization process] // Visnyk Cherkaskoho universytetu. Seriia istorychni nauk № 35 (248) [Bulletin of the Cherkassy University. A series of historical sciences]. Cherkasy, 2012. Pp. 15-18. [in Russian]

Sviashchenko, 2012 - Sviashchenko Z. Prouriadovi ahrarni initsiatyvy v Rosiiskii imperii na pochatku KhKh st. [Pro-government agricultural initiatives in the Russian Empire in the early twentieth century]. Uman: FOP Zhovtyi O.O., 2012. 343 s. [in Ukrainian].

Trapeznikov, 1976 - Trapeznikov S. P. Leninizm i agrarno-krest'yanskij vopros [Lenynyzm and the agro-peasant issue]: V 2 t. T. 1. Moskva: Mysl', 1976. 567 p. [in Russian]

Стаття надійшла до редакиії 10.04.2018 p. 